\title{
Enriched animal manure as a source of phosphorus in sustainable agriculture
}

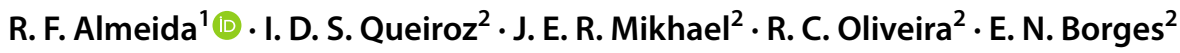

Received: 30 January 2019 / Accepted: 20 July 2019 / Published online: 30 July 2019

(c) The Author(s) 2019

\begin{abstract}
Purpose Due to the pressures of conforming to environmental quality standards and the increased costs of mineral fertilizer importation, there is growing interest in the use of organic residues as fertilizers. To test the hypothesis that indicates the quantity of animal manure (AM) depends on the phosphorus (P) needs of the crops, an experiment was run using three organic animal manures (chicken-CM, turkey-TM, and cow manure-CoM), enriched with limestone, gypsum, and phosphorus. Methods A greenhouse experiment was run using AM incorporated in a clayey soil, at a rate that equates to the $\mathrm{P}$ needs of Brachiaria sp. Contents of phosphorus, potassium $\left(\mathrm{K}^{+}\right)$, calcium $\left(\mathrm{Ca}^{+2}\right)$, magnesium $\left(\mathrm{Mg}^{+2}\right)$, sodium $\left(\mathrm{Na}^{+}\right)$, organic matter $(\mathrm{OM})$, and values of $\mathrm{pH}$ and cation exchange capacity (CEC) were monitored during 120 days. Plants were collected to determine the dry matter.

Results Application of enriched $\mathrm{AM}$ increased the contents of $\mathrm{Ca}, \mathrm{Mg}$, and $\mathrm{K}$ over time, while $\mathrm{P}$ and $\mathrm{OM}$ presented a decrease. Soil fertilized with CoM resulted in the greatest contents of $\mathrm{P}$ and OM, while soil with TM presented the highest production of dry matter with the lowest contents of $\mathrm{P}$ in soil. There was an increase in Na content in soil with the application of AM.

Conclusion Fertilization with AM presents the potential to supply $\mathrm{P}, \mathrm{Ca}, \mathrm{Mg}$ and $\mathrm{K}$ for plants. Enriched CoM appears to be the most viable option to improve the phosphorus and organic matter in soil because of high $\mathrm{C} / \mathrm{N}$. However, farmers may need to pay attention to the quantity of $\mathrm{Na}$.
\end{abstract}

Keywords Chicken manure $\cdot$ Turkey manure $\cdot$ Cow manure $\cdot$ Organic fertilizer

\section{Introduction}

Farmers have used animal manure (AM) for several years as a primary source of nutrients to fertilize agricultural soils. With the development of mineral fertilizers, interest in this type of fertilizer has decreased (Muraishi et al. 2011). However, due to the growing pressures of conforming to environmental quality standards (Carvajal-Muñoz and CarmonaGarcia 2012), and increase in the costs of importing mineral fertilizers (ANDA 2016), there is an interest in the use of

R. F. Almeida

rizely@gmail.com

1 Soil Department, University of São Paulo (USP), Av. Pádua Dias 11, Bairro Agronomia, Piracicaba, SP CP 9, Brazil

2 Institute of Agrarian Science, University of Uberlândia (UFU), Av Pará 1720. Bairro Umuarama, Uberlândia, MG CP 593, Brazil organic residues as a source of nutrients in agriculture leading to an expansion of research in this area.

The AM is a by-product of poultry and livestock production. The quality of AM as soil fertilizer can vary greatly depending on the kind of manures, treatments, and decompositions. Manure from livestock production (cow manure) contains high concentrations of available nutrients (Hariadi et al. 2016), mainly nitrogen (N), phosphorus (P) and sulfur (S), (Muraishi et al. 2011), while the manure from poultry production (chicken and turkey manure) contains high concentrations of potassium (K) and $\mathrm{P}$ (Pinto et al. 2012).

The process of organic composting is a technique that reduces problems with pathogens and enhances nutrient availability to plants. Composting of manures with limestone and gypsum is an alternative of enrichment, considered a viable alternative for increasing nutrient availability (Ramos et al. 2013). However, this technique needs to be more thoroughly studied because of the possible increase of $\mathrm{P}$ adsorption in soil and a subsequent imbalance between the bases 
(magnesium- $\mathrm{Mg}$, calcium- $-\mathrm{Ca}$, potassium-K) with the formation of percolating sulfates in soil (Ramos et al. 2013).

In addition, farmers should pay attention to the quality and quantity of animal manure used as a source of nutrients in the soil. Both quality and quantity can cause an excessive input of nutrients in the soil leading to soil pollution and groundwater contamination, and soil disuse for agricultural purposes (Min et al. 2012).

To test the hypothesis that the quantity of AM depends on the phosphorus needs of crops, an experiment was run with the aim of testing three organic animal manures (chicken, turkey, and cow manure), enriched with limestone, gypsum, and phosphorus.

\section{Materials and methods}

\section{Soil and manure characteristics}

The experiment was conducted in a greenhouse located at the University of Uberlândia (UFU), Uberlândia campus, Brazil $\left(18^{\circ} 54^{\prime} 41^{\prime \prime} \mathrm{S}\right.$ and $\left.48^{\circ} 15^{\prime} 44^{\prime \prime} \mathrm{W}\right)$. The experimental design was arranged as a complete randomized block using three kinds of organic animal manure (chicken manure-CM, turkey manure-TM, and cow manure-CoM), enriched with limestone (L), gypsum (G) and $\mathrm{L}+\mathrm{G}+\mathrm{P}$, with three replicates. Two control plots were also run using natural manure (Natural) and mineral fertilizer without manure (P mineral).

The soil was collected at depths ranging from 0 to $0.2 \mathrm{~m}$, from six positions (replicated in 1 hectare), in an area cultivated with pasture (Brachiaria sp.), located in Uberlândia $\left(18^{\circ} 45^{\prime} 50.74^{\prime \prime} \mathrm{S}\right.$ and $\left.48^{\circ} 17^{\prime} 15.36^{\prime \prime} \mathrm{W}\right)$. Soil samples were homogenized and subjected to chemical and physical analysis according to Embrapa (2013). The soil was classified as a Latossolo Vermelho-Amarelo Distrófico típico according to the Brazilian system of Soil Classification (Embrapa 2013), corresponding to an Oxysol according to soil taxonomy (Soil Survey Staff 2014).

Chemical analysis of soil samples before the implementation of experiment showed the following contents: P: $1.7 \mathrm{mg} \mathrm{dm}^{-3}$ (Mehlich I); K: $15.6 \mathrm{mg} \mathrm{dm}^{-3}$; Ca: $1.6 \mathrm{cmol}_{\mathrm{c}}$ $\mathrm{dm}^{-3} ; \mathrm{Mg}$ : $0.4 \mathrm{cmol}_{\mathrm{c}} \mathrm{dm}^{-3}$; hydrogen + aluminum- $\mathrm{H}+\mathrm{Al}$ : $1.2 \mathrm{cmol}_{\mathrm{c}} \mathrm{dm}^{-3}$; aluminum: $\mathrm{Al}^{3+}: 0.0 \mathrm{cmol}_{\mathrm{c}} \mathrm{dm}^{-3}$; organic matter-OM: $1.3 \mathrm{~g} \mathrm{dm}^{-3}$; organic carbon-OC: $0.8 \mathrm{~g} \mathrm{dm}^{-3}$; and total nitrogen-TN: $0.7 \mathrm{~g} \mathrm{~kg}^{-1}$. Soil presented a clay texture with 664,265 and $71 \mathrm{~g} \mathrm{~kg}^{-1}$ of clay, silt, and sand, respectively. Clayey soil was used in this study because of the significant correlation with most metals and nutrients in the tropical soil with the predominance of kaolinite and iron and aluminum oxides in clay (Nascimento et al. 2018), as well as a direct relation to $\mathrm{P}$ adsorption on clay surface (Fischer et al. 2018).
The manures were collected from rural properties and handled in the laboratory. For natural manure plots, the manures were maintained under ambient conditions with good ventilation for drying. Contrastingly, the enriched manure treatments with limestone $\left(\mathrm{CaCO}_{3}\right.$; Rate: $\left.5 \mathrm{Mg} \mathrm{ha}^{-1}\right)$, gypsum $\left(\mathrm{CaSO}_{4}\right.$; Rate: $\left.2 \mathrm{Mg} \mathrm{ha}^{-1}\right)$ and simple superphosphate ( $18 \%$ of P; Rate: $600 \mathrm{~kg} \mathrm{ha}^{-1}$ ) were treated following the guidelines of (Embrapa 2001). After the maturation process was completed, the manure samples were homogenized and subjected to chemical analysis (Embrapa 2011), Table 1.

\section{Installation of sets}

Soil $\left(2.5 \mathrm{~kg} \mathrm{pot}^{-1}\right)$ was added in pots (height: $20 \mathrm{~cm}$, total volume of $2.5 \mathrm{~L}$, subdivided into two parts), and manure was incorporated using the rates of $6.9,5.9,5.4,6.9 \mathrm{~g}$ to $\mathrm{CM}$; 4.9, 7.0, 5.6, 7.2 $\mathrm{g}$ to TM and 16.8, 26.0, 28.9, $31.0 \mathrm{~g}$ to $\mathrm{CoM}$, respectively, using $\mathrm{L}, \mathrm{G}, \mathrm{L}+\mathrm{G}+\mathrm{P}$ and the natural control (Fig. 1). The manure rates were calculated based on mineral control (mineral fertilizer without manure), with a similar rate of $126 \mathrm{~kg} \mathrm{P}_{2} \mathrm{O}_{5} \mathrm{ha}^{-1}$ to all treatments in this study.

The Brachiaria sp. seeds were sowed using a density of 30 seeds pot $^{-1}$, and after germination a density of 10 plants pot $^{-1}$ was maintained. Irrigation was performed every day to maintain the water retention capacity at $60 \%$. This study was performed with Brachiaria to show a sustainable alternative of soil fertilization in pasture areas. $27 \%$ of Brazil's territory is being used for agriculture or as pastures. Pastures occupy most of these areas with $76 \%$ of the total agricultural land, with high susceptibility to soil degradation due to the absence of adequate technologies such as the application of nutrients (Sparovek et al. 2007).

\section{Variables analyzed and statistical analysis}

Contents of $\mathrm{K}^{+}, \mathrm{Ca}^{+2}, \mathrm{Mg}^{+2}, \mathrm{P}, \mathrm{OM}$ and sodium $\left(\mathrm{Na}^{+}\right)$, and values of cation exchange capacity (CEC) and $\mathrm{pH}$ were analyzed at the 40th, 90th and 120th day after implantation of the experiment, by removing soil samples from the top $0.1 \mathrm{~m}$ layer of pots (surface). The third evaluation was performed at $0.0-0.1 \mathrm{~m}$ (surface) and $0.1-0.2 \mathrm{~m}$ (subsurface) layers at the 120th day after the implantation of the experiment. At the same time, plants were collected, dried and weighed to obtain the dry matter per pot. Contents of nutrients in soil samples were analyzed according to Embrapa (2011).

Data were evaluated by descriptive statistics, assumptions of normality (Shapiro-Wilk test) and homogeneity of variance (Bartlett test). The difference among treatments was assessed using analysis of variance (ANOVA), based on the $F$ test when significant and a post hoc test was run using the Tukey test $(P<0.5)$. 
Table 1 Manure chemical analysis (chicken, turkey and cow manure) in natural manure and manure enriched with limestone $(\mathrm{L})$, gypsum $(\mathrm{G})$ and phosphorus (P)

\begin{tabular}{|c|c|c|c|c|c|c|c|c|c|c|c|c|c|c|}
\hline Animal manure & $\mathrm{pH}$ & $\begin{array}{r}\mathrm{C} / \mathrm{N} \\
(\%)\end{array}$ & $\mathrm{C}$ & $\mathrm{P}_{2} \mathrm{O}_{5}$ & $\mathrm{~K}_{2} \mathrm{O}$ & $\mathrm{Ca}$ & $S$ & $\mathrm{Mg}$ & $\begin{array}{l}\text { B } \\
(\mathrm{mg} \mathrm{k}\end{array}$ & $\begin{array}{c}\mathrm{Cu} \\
\left.\mathrm{g}^{-1}\right)\end{array}$ & $\mathrm{Fe}$ & $\mathrm{Mn}$ & $\mathrm{Zn}$ & $\mathrm{Na}$ \\
\hline \multicolumn{15}{|c|}{ Chicken manure $(\mathrm{CM})^{\mathrm{a}}$} \\
\hline In natural & 8.1 & $14 / 1$ & 50.6 & 2.1 & 2.6 & 2.9 & 0.3 & 0.5 & 38.1 & 156 & 5603 & 603 & 440 & 1675 \\
\hline Limestone & 8.7 & $14 / 1$ & 24.9 & 1.7 & 1.6 & 2.1 & 0.2 & 0.4 & 27.3 & 107 & 3880 & 434 & 356 & 1965 \\
\hline Gypsum & 8.7 & $14 / 1$ & 24.0 & 1.7 & 1.6 & 2.0 & 0.4 & 0.2 & 27.2 & 106 & 3750 & 475 & 325 & 1945 \\
\hline $\mathrm{L}+\mathrm{G}+\mathrm{P}$ & 8.6 & $13 / 1$ & 26.0 & 1.5 & 1.7 & 2.2 & 0.4 & 0.3 & 26.1 & 109 & 4012 & 415 & 345 & 2269 \\
\hline \multicolumn{15}{|c|}{ Turkey manure $(\mathrm{TM})^{\mathrm{a}}$} \\
\hline In natural & 7.8 & $9 / 1$ & 69.3 & 2.9 & 2.6 & 3.2 & 0.3 & 0.4 & 39.5 & 428 & 1745 & 458 & 396 & 1754 \\
\hline Limestone & 8.3 & $11 / 1$ & 28.7 & 1.3 & 1.3 & 1.3 & 0.1 & 0.2 & 20.3 & 208 & 1359 & 239 & 185 & 1700 \\
\hline Gypsum & 8.2 & $11 / 1$ & 27.0 & 1.3 & 1.3 & 1.4 & 1.4 & 0.2 & 21.2 & 210 & 1458 & 237 & 180 & 1740 \\
\hline $\mathrm{L}+\mathrm{G}+\mathrm{P}$ & 8.0 & $10 / 1$ & 29.4 & 1.3 & 1.3 & 1.5 & 0.3 & 0.2 & 21.0 & 223 & 2759 & 233 & 195 & 1864 \\
\hline \multicolumn{15}{|c|}{ Cow manure $(\mathrm{CoM})^{\mathrm{a}}$} \\
\hline In natural & 8.3 & $22 / 1$ & 43.6 & 0.8 & 1.4 & 1.4 & 0.1 & 0.3 & 16.3 & 62.4 & 5524 & 438 & 239 & 748 \\
\hline Limestone & 8.6 & $21 / 1$ & 18.9 & 0.3 & 0.6 & 0.6 & 0.1 & 0.1 & 8.0 & 28.2 & 3242 & 204 & 105 & 343 \\
\hline Gypsum & 8.5 & $21 / 1$ & 17.8 & 0.2 & 0.5 & 0.7 & 0.2 & 0.1 & 8.2 & 20.3 & 3250 & 200 & 1.3 & 350 \\
\hline $\mathrm{L}+\mathrm{G}+\mathrm{P}$ & 8.3 & $17 / 1$ & 15.6 & 0.3 & 0.5 & 0.7 & 0.1 & 0.1 & 7.2 & 28.1 & 2086 & 202 & 109 & 338 \\
\hline
\end{tabular}

$\mathrm{pH}$ in $\mathrm{H}_{2} \mathrm{O}$, carbon and nitrogen ratio $(\mathrm{C} / \mathrm{N})$, carbon $(\mathrm{C})$, phosphorus $\left(\mathrm{P}_{2} \mathrm{O}_{5}\right)$, potassium $\left(\mathrm{K}_{2} \mathrm{O}\right)$, calcium $\left(\mathrm{Ca}^{2+}\right)$, sulfur $(\mathrm{S})$, magnesium $\left(\mathrm{Mg}^{2+}\right)$, boron $(\mathrm{B})$, copper $(\mathrm{Cu})$, iron $(\mathrm{Fe})$, manganese $(\mathrm{Mn})$, zinc $(\mathrm{Zn})$, and sodium $(\mathrm{Na})$

${ }^{\mathrm{a}} \mathrm{CM}(10.4 \%)$, TM (12.5\%) and CoM moisture (13.8\%)
Fig. 1 Experiment at the greenhouse
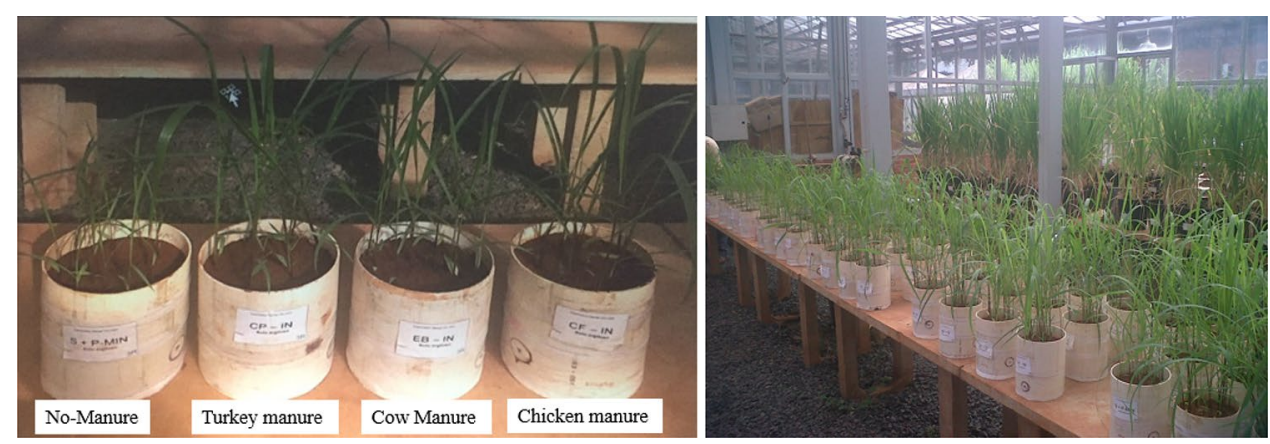

The temporal dynamics were tested using principal component analysis (PCA). To obtain zero mean and constant variance, the data were standardized and the Euclidean distance between data points was calculated using the Ward algorithm. The principal components (PCs) that presented eigenvalues greater than 1 were used, and the PCA was presented graphically to identify and evaluate time groupings.

\section{Results and discussion}

\section{Temporal dynamics}

The PCs highlighted differences in the temporal dynamics through the formation of two distinct groups. The first and second period presented similar patterns with insertion at group 1. Both periods presented a significant difference in the third period, which was inserted in group 2 (Fig. 2). Study of Behera et al. (2018) and Coletto et al. (2015) also used PCs to show nutrient dynamics over time in soil. Applications of animal manure take 90 days to increase the content of nutrients in the soil, with the first 30 days showing a greater release rate and a subsequent decline (Silva et al. 2014). The remaining nutrients in animal manure take more time to be released in the soil as long as 2.5 years (Hoffmann et al. 2001), but this will depend greatly on the quality of animal manure (Azeez and Averbeke 2010; Silva et al. 2014). According to Tripetchkul et al. (2012), greater decomposition of organic matter occurs within the first 2 weeks of the thermophilic phase in organic residues with a low $\mathrm{C} / \mathrm{N}$ ratio.

Three PCs were necessary to explain the temporal dynamics, with the variance concentrated along PC1, which explained $47 \%$ of the variation in data, followed by $\mathrm{PC} 2$ 
Fig. 2 Principal component analysis (PCA) for the variables: $\mathrm{pH}$, phosphorus $(\mathrm{P})$, potassium $\left(\mathrm{K}^{+}\right)$, calcium $\left(\mathrm{Ca}^{+2}\right)$, magnesium $\left(\mathrm{Mg}^{+2}\right)$, cation exchange capacity (CEC), sodium $\left(\mathrm{Na}^{+}\right)$ and organic matter $(\mathrm{OM})$ in the first, second and third period (surface and subsurface)

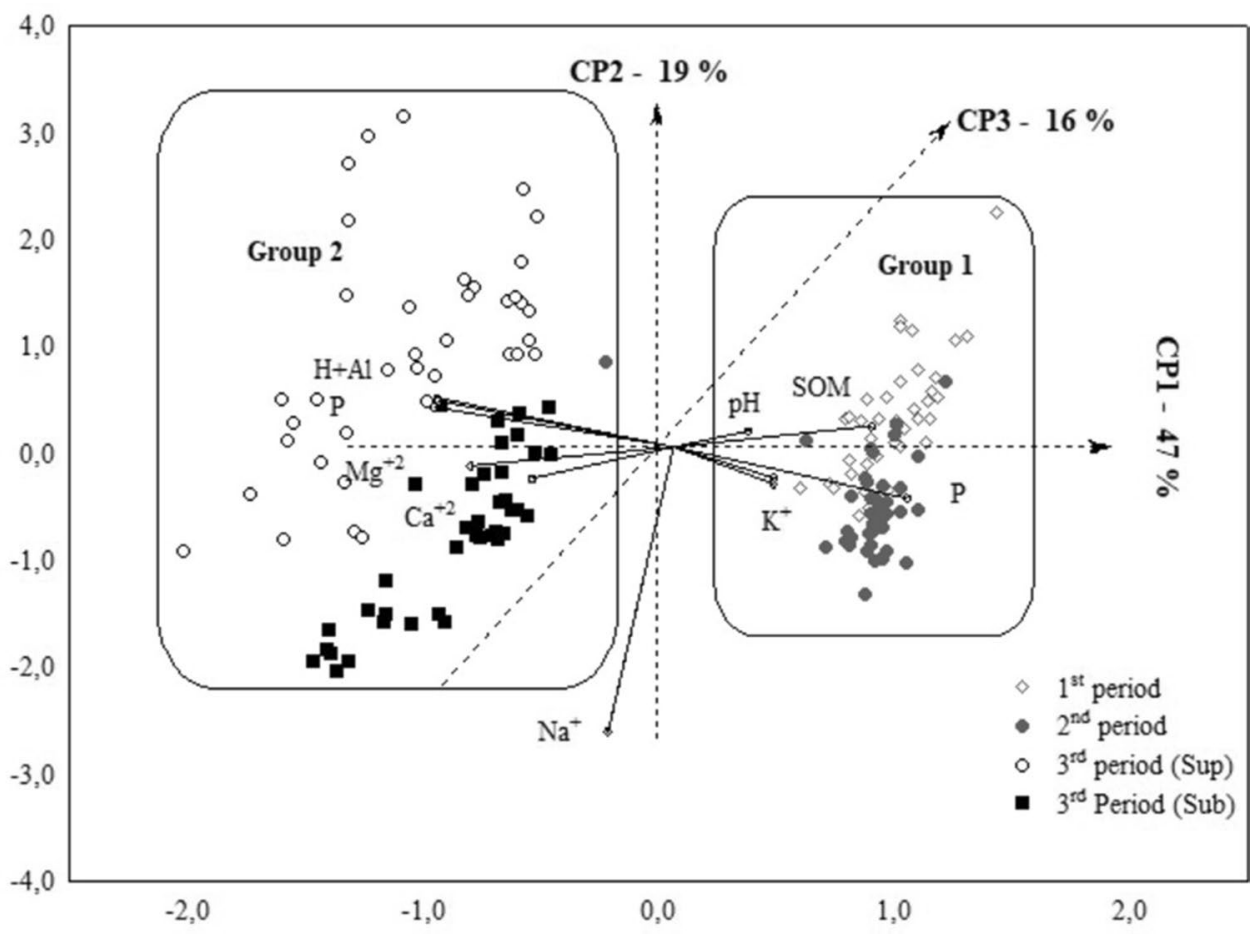

Table 2 Principal component (PC) values for the variables: $\mathrm{pH}$, phosphorus $(\mathrm{P})$, potassium $\left(\mathrm{K}^{+}\right)$, calcium $\left(\mathrm{Ca}^{+2}\right)$, magnesium $\left(\mathrm{Mg}^{+2}\right)$, sodium $\left(\mathrm{Na}^{+}\right)$, organic matter $(\mathrm{OM})$ and cation exchange capacity (CEC)

\begin{tabular}{lccc}
\hline Variables & PC1 (47\%) & PC2 (19\%) & PC3 (16\%) \\
\hline $\mathrm{pH}$ & 0.26 & $\mathbf{- 0 . 7 5}$ & -0.10 \\
$\mathrm{~K}^{+}$ & 0.32 & $\mathbf{- 0 . 6 7}$ & 0.00 \\
$\mathrm{Ca}^{2+}$ & $\mathbf{- 0 . 8 4}$ & -0.45 & 0.07 \\
$\mathrm{Mg}^{2+}$ & $\mathbf{- 0 . 6 0}$ & -0.66 & 0.12 \\
$\mathrm{Na}^{+}$ & -0.22 & 0.05 & $\mathbf{0 . 9 4}$ \\
$\mathrm{OM}$ & $\mathbf{0 . 7 7}$ & -0.15 & -0.15 \\
$\mathrm{P}$ & $\mathbf{0 . 9 3}$ & 0.01 & 0.18 \\
$\mathrm{CEC}$ & $\mathbf{- 0 . 9 3}$ & 0.13 & -0.16 \\
\hline
\end{tabular}

Bold correlations are considered significant $(r>0.5$ in absolute values)

and PC3 with $19 \%$ and $16 \%$, respectively (Fig. 2). These PCs together accounted for $89 \%$ of the total variance and conformed to the criteria of at least $70 \%$, as demonstrated in the study of Faria et al. (2019).

\section{Nutrients release in the periods}

With respect, $\mathrm{PC} 1, \mathrm{Ca}^{+2}(r=-0.84), \mathrm{Mg}^{+2}(r=-0.60)$ and CEC $(r=-0.93)$ were negatively correlated, while $\mathrm{P}$ $(r=0.93), \mathrm{OM}(r=0.77)$ were positively correlated in the principal component analysis (Table 2; Fig. 2).
There was a small difference, without significant distinction in contents of $\mathrm{Ca}^{+2}, \mathrm{Mg}^{+2}$ and $\mathrm{P}$ in the first and second period. Such minimal variation is likely to reflect the fact that these animal manures are enriched with lime which presented $\mathrm{Ca}$ and $\mathrm{Mg}$ in their compositions and require almost 60 days to release the nutrients into the soil solution. It can be observed in Fig. 3, where $\mathrm{Ca}^{+2}$ and $\mathrm{Mg}^{+2}$ increased in the surface layer in the third period, which can be explained by the strong affinity of $\mathrm{Ca}^{+2}$ and $\mathrm{Mg}^{+2}$ with soil colloids leading to low rates of leaching, as well as the low reactivity of lime (Maggi et al. 2011).

The significant decrease in $\mathrm{P}$ after the second period (90\% lower; Fig. 3) is explained by the dynamics of P which can be readily adsorbed on the clay surface. This kind of adsorption reaction is a characteristic of soils with a high presence of the minerals: kaolinite, iron and aluminum oxides, which are typically evident in tropical soils with a clay texture (Nascimento et al. 2018; Campos et al. 2016). As expected, organic matter also presented a decrease over time (53\% less) due to higher soil microbial activities. The distinct results demonstrated by PC1 are reaffirmed by the positive correlation between $\mathrm{P}$ and $\mathrm{OM}$ (decrease over time) and the negative relationship between $\mathrm{Ca}^{+2}, \mathrm{Mg}^{+2}$ and CEC (an increase over time), Table 2.

At PC2, $\mathrm{K}^{+}(r=-0.6)$ presented a decrease occurring since the first period and reaching a total decline of $78 \%$ in the third period (Table 2; Fig. 3). This can be explained by the fact that $\mathrm{K}^{+}$demonstrates high mobility in soil profile with vertical and horizontal movements, and thus $\mathrm{K}^{+}$ 

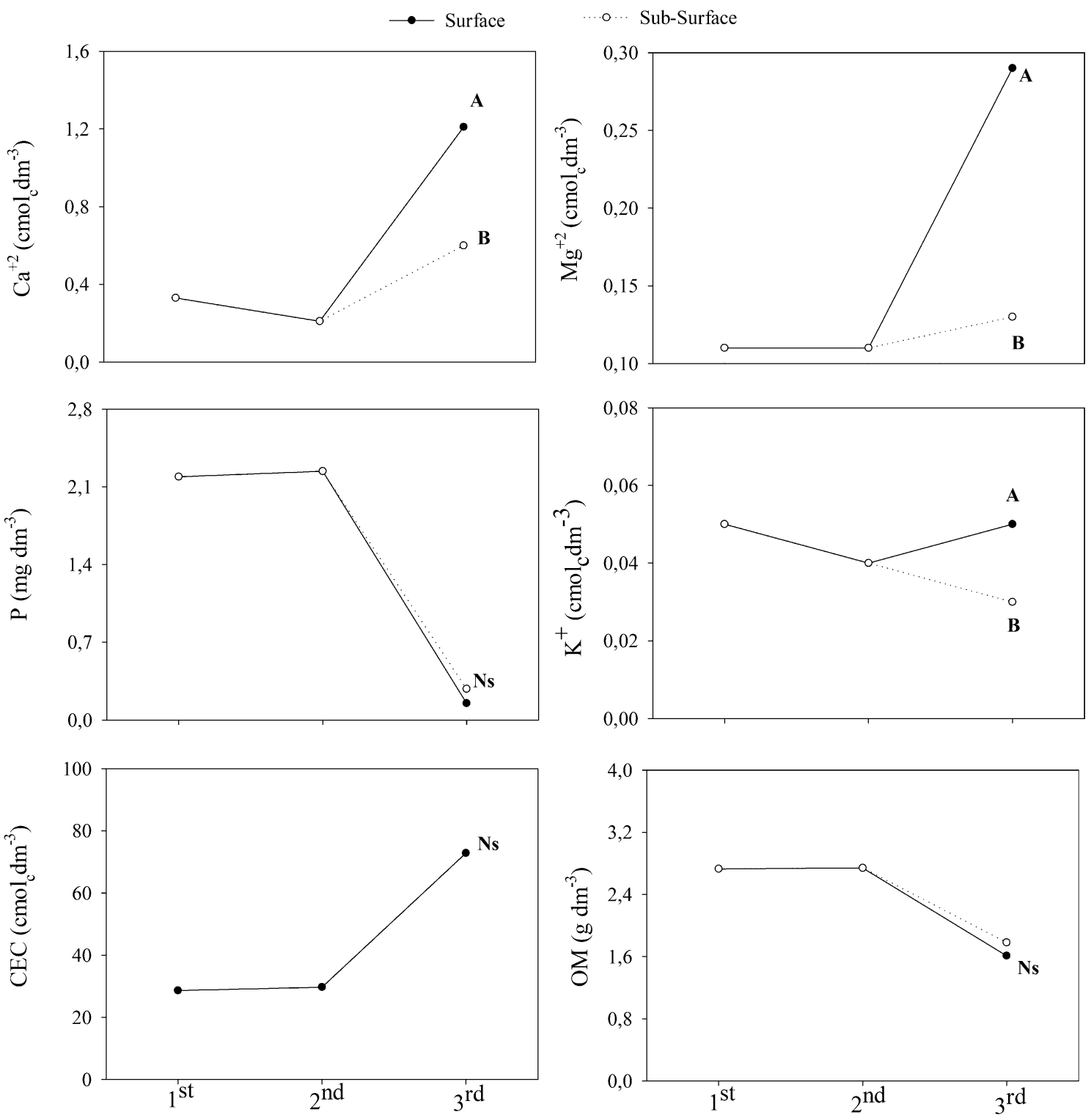

Evaluation time (Periods)

Fig. 3 Calcium $\left(\mathrm{Ca}^{+2}\right)$, potassium $\left(\mathrm{K}^{+}\right)$, phosphorus $(\mathrm{P})$, magnesium $\left(\mathrm{Mg}^{+2}\right)$, organic matter $(\mathrm{OM})$ and cation exchange capacity $(\mathrm{CEC})$ in the first, second and third period (surface and subsurface)

is considered as a soluble ion that can be percolated in soil solution, especially in sandy soils (Ramos et al. 2013).

At PC3, $\mathrm{Na}^{+}$was alone $(r=0.94)$ and presented a result that was distinct from the other nutrients (Table 2). This finding is associated with the $\mathrm{Na}^{+}$increase of $33 \%$ (mean of animal manure) when compared to mineral $P$. There was no difference in the content of $\mathrm{Na}^{+}$with the application of animal manures representing a difference of $0.5 \mathrm{cmol}_{c} \mathrm{dm}^{3}$ across treatments (Fig. 4). This is not a great result because the increase in $\mathrm{Na}^{+}$content in the soil increases the electrical conductivity and decreases osmotic potential, creating disturbance and compromising the development of plants (Silva et al. 2010). In addition, an excess of $\mathrm{Na}^{+}$during root growth promotes competition for absorption sites, especially for $\mathrm{K}^{+}$, $\mathrm{Ca}^{2+}$, and $\mathrm{Mg}^{2+}$, leading to nutrient deficiencies of these nutrients in plants (Trannin et al. 2005). Study of Oliveira et al. (2014) demonstrated the toxic effects of $\mathrm{Na}^{+}$on lettuce in soil with the application of animal manure. While Sharma et al. (2019) testing domestic residues as a source of nutrient in agriculture verified low fertilizing potential due to heavy metal concentration. In this study, we did not monitor the dynamic of heavy metal but in the future study of animal manure application, we recommend heavy metal monitoring to avoid soil contamination. 

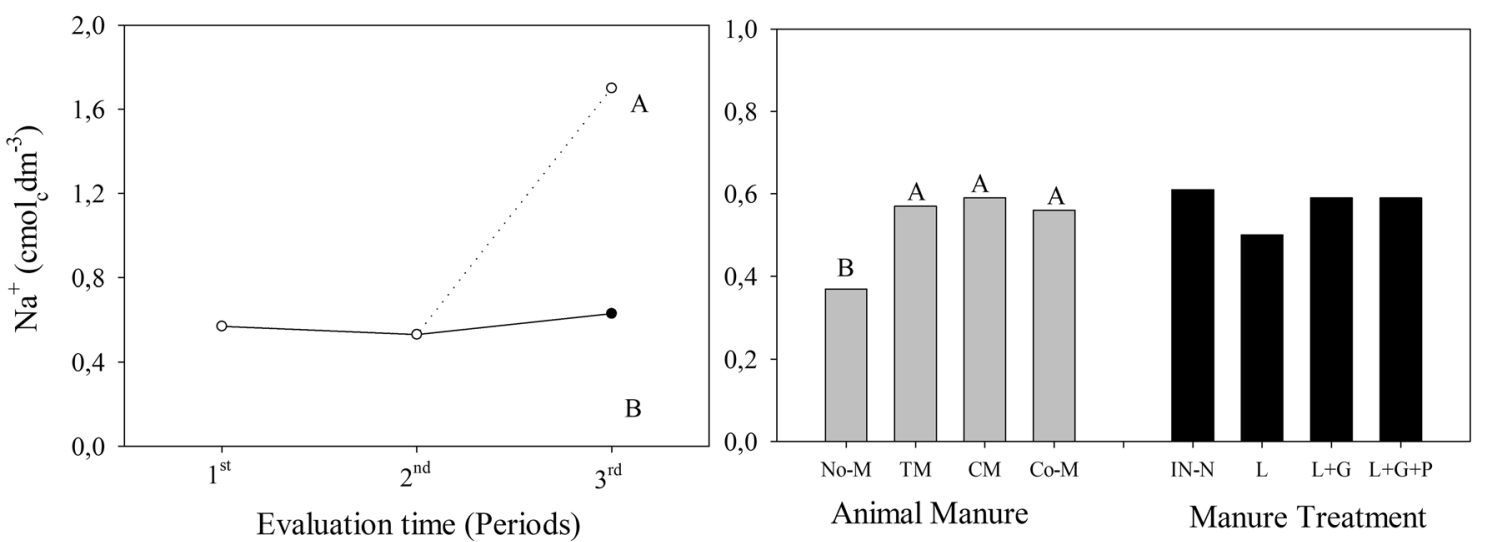

Fig. 4 Sodium $\left(\mathrm{Na}^{+}\right)$in soil with application of animal manure (turkey: TM, chicken: CM, and cow manure: CoM) enriched with limestone (L), gypsum $(\mathrm{G})$ and phosphorus (P), check treatment (No-Manure: No-M; and No-enrichment: IN-N) in the first, second and third period

Table 3 Dry matter of brachiaria (DM), values of $\mathrm{pH}$ and contents of phosphorus $(\mathrm{P})$, calcium $\left(\mathrm{Ca}^{+2}\right)$, magnesium $\left(\mathrm{Mg}^{+2}\right)$, potassium $\left(\mathrm{K}^{+}\right)$and organic matter $(\mathrm{OM})$ in soil with application of animal manure (turkey: TM, chicken: $\mathrm{CM}$ and cow manure: CoM) enriched with limestone (L), gypsum $(\mathrm{G})$ and phosphorus $(\mathrm{P})$, check plot (NoManure: $\mathrm{P}$ mineral, and No-enrichment: in natural)

\begin{tabular}{|c|c|c|c|c|c|c|c|}
\hline Animal manure & $\mathrm{DM}\left(\mathrm{g} \mathrm{pot}^{-1}\right)$ & $\mathrm{OM}\left(\mathrm{g} \mathrm{dm}^{-3}\right)$ & $\mathrm{pH}$ & $\mathrm{P} \mathrm{mg} \mathrm{dm}{ }^{-3}$ & $\begin{array}{l}\mathrm{K}^{+} \\
\mathrm{cmol}_{\mathrm{c}}\end{array}$ & $\mathrm{Mg}^{+2}$ & $\mathrm{Ca}^{+2}$ \\
\hline \multicolumn{8}{|l|}{ Animal manures* } \\
\hline $\mathrm{P}$ mineral & $3.15 \mathrm{c}$ & $2.68 \mathrm{~b}$ & $5.60 \mathrm{~b}$ & $1.70 \mathrm{~b}$ & $0.03 b$ & $0.13 \mathrm{a}$ & $0.32 \mathrm{a}$ \\
\hline $\begin{array}{l}\text { Turkey } \\
\text { manure } \\
(\mathrm{TM})\end{array}$ & $8.71 \mathrm{a}$ & $2.76 \mathrm{ab}$ & $5.71 \mathrm{a}$ & $2.04 b$ & $0.05 \mathrm{a}$ & $0.11 \mathrm{Ab}$ & $0.27 \mathrm{a}$ \\
\hline $\begin{array}{c}\text { Chicken } \\
\text { manure } \\
(\mathrm{CM})\end{array}$ & $7.55 b$ & $2.69 \mathrm{ab}$ & $5.56 \mathrm{~b}$ & $2.40 \mathrm{a}$ & $0.04 \mathrm{a}$ & $0.10 \mathrm{~b}$ & $0.31 \mathrm{a}$ \\
\hline $\begin{array}{l}\text { Cow manure } \\
(\mathrm{CoM})\end{array}$ & $7.21 \mathrm{~b}$ & $2.82 \mathrm{a}$ & $5.77 \mathrm{a}$ & $2.40 \mathrm{a}$ & $0.05 \mathrm{a}$ & $0.10 \mathrm{~b}$ & $0.29 \mathrm{a}$ \\
\hline \multicolumn{8}{|c|}{ Enrichment technique $^{\mathrm{ns}}$} \\
\hline In natural & $8.62 \mathrm{a}$ & 2.70 & 5.75 & 2.30 & 0.04 & 0.10 & 0.30 \\
\hline $\begin{array}{l}\text { Limestone } \\
\text { (L) }\end{array}$ & $6.97 \mathrm{~b}$ & 2.72 & 5.64 & 2.14 & 0.05 & 0.11 & 0.29 \\
\hline $\begin{array}{l}\mathrm{L}+\text { gypsum } \\
(\mathrm{G})\end{array}$ & $6.97 \mathrm{ab}$ & 2.77 & 5.64 & 2.36 & 0.05 & 0.10 & 0.28 \\
\hline $\begin{array}{l}\mathrm{L}+\mathrm{G}+\text { phos- } \\
\text { phorus }\end{array}$ & $8.10 \mathrm{ab}$ & 2.78 & 5.64 & 2.36 & 0.05 & 0.10 & 0.30 \\
\hline $\mathrm{CV}(\%)$ & 1.00 & 0.7 & 1.64 & 0.23 & 0.05 & 0.01 & 0.04 \\
\hline
\end{tabular}

ns: no difference between the treatments

*mean followed by distinct letters are considered significant by the Tukey' test $(P<0.05)$

\section{Nutrients released from animal manures}

The TM and mineral $\mathrm{P}$ presented lower contents of $\mathrm{P}$ in soil when compared to CoM and CM (Table 3). This can be explained by greater biological activity in TM, which yielded the lowest $\mathrm{C} / \mathrm{N}$ values and provided the highest dry matter of Brachiaria due to high P availability to plants (Tables 1 and 3). According to Boitt (2014), the addition of organic residues with low $\mathrm{C} / \mathrm{N}$ in soil provides an increase in microbial biomass that drives low $\mathrm{P}$ adsorption in soil, as demonstrated by a negative correlation between OM and P in the study of Moura et al. (2015). Probably, manures can alter biological activity in soil influencing the nutrients' dynamics. Future studies using this perspective are recommended to understand the influence of animal manure on biological activity in the soil.

On the other hand, because the CoM showed the highest $\mathrm{C} / \mathrm{N}$, it appears to be the best option to improve OM in 
soils, but even that presents a low content of K (Tables 1 , $3)$. The results of CoM characterized it as a manure of slow decomposition with $28 \%$ of the material decomposed within 90 days. Slow decomposition of CoM in soil was presented by the study of Azeez and Averbeke (2010) and Silva et al. (2014).

The increase in organic matter temporally promotes an adsorption of $\mathrm{P}$ in soil (Muraishi et al. 2011; Maciel et al. 2015; Abreu et al. 2016), with a lower nutrient loss by run off and leaching while maintaining an optimal condition of $\mathrm{pH}$, soil moisture and soil biological activity (Moreti et al. 2007). The increase in $\mathrm{pH}$ observed for all manures is directly related to higher micronutrient availability $(\mathrm{B}, \mathrm{Cu}$, $\mathrm{Fe}, \mathrm{Mn}$, and $\mathrm{Zn}$ ) in the soil which is probably transferred from manure to soil. The $\mathrm{pH}$ increase in soil incorporated with animal manure has also been shown by Abreu et al. (2016) and Damatto Junior et al. (2006).

The differences in response to manure types were expected, because the nutrient release from materials depends on the feedstock and nutrient dynamics (Freitas et al. 2012). However, with respect to $\mathrm{K}$, there was no apparent difference among manure types (Table 1). The effect of $\mathrm{TM}$ and $\mathrm{CM}$ on $\mathrm{K}$ described in this test has also been shown by Pinto et al. (2012) with high leaching of $\mathrm{K}$ in soil.

There was no difference between the enriched manure and the natural manure in terms of nutrients. However, the dry matter presented a significant difference with an increase in natural manure (Table 3). This means that farms can use the animal manure naturally (dry) without enrichment with limestone, gypsum, and phosphorus, since the rates were adequate enough to supply the $\mathrm{P}$ needs of pasture in clay soil.

\section{Conclusions}

Application of enriched animal manure in a clayey soil alter nutrient dynamics which can be represented by two distinct groups: similar nutrient dynamics up until 60 days (group 1 , first and second period), and a distinct trend from 61 to 120 days (group 2, third period).

Cow manure appears to be the most viable option to improve the contents of phosphorus and organic matter in soil due to the high $\mathrm{C} / \mathrm{N}$ ratio, without any difference between the natural manure and manure enriched with limestone, gypsum, and phosphorus. In contrast, turkey manure presents the highest pasture dry matter production with a high availability of nutrients to plant. Farmers may need to pay attention to the quality of manure, especially for the quantity of sodium in areas where there is continuous fertilization using animal manures.

Overall, animal manure is a sustainable alternative of the source of nutrient to plant when applied according to $\mathrm{P}$ needs of plants. Technologies to improve the efficiency of animal manure as fertilizer are requested to achieve environmental quality standards and decrease the dependence of mineral fertilizer. Based on this, organo-mineral fertilizers formulated from different animal manures (Mota et al. 2019) enriched with rock phosphates (Unuofin and Siswana 2019) or treated as biochar (Sikder and Joardar 2019) demonstrate to be an alternative that can make tropical agriculture more efficient and sustainable.

Authors' contribution R. F. Almeida, I. D. S. Queiroz and J. E. R. Mikhael carried out the experiment. R. F. Almeida, R. C. Oliveira and E. N. Borges carried out the experiment and contributed to the interpretation of the results. All the authors discussed the results, commented on the manuscript and contributed to the final manuscript.

Funding This study was not funded.

\section{Compliance with ethical standards}

\section{Conflict of interest There is no conflict of interest.}

Open Access This article is distributed under the terms of the Creative Commons Attribution 4.0 International License (http://creativeco mmons.org/licenses/by/4.0/), which permits unrestricted use, distribution, and reproduction in any medium, provided you give appropriate credit to the original author(s) and the source, provide a link to the Creative Commons license, and indicate if changes were made.

\section{References}

Abreu SAH, Arruda EM, Barros LR, Almeida RF, Maranhão DDC, Silva VL, Silva Neto CM, Flores RA, Calil FN, Collier LS (2016) Chemical attributes of the soil in agroforestry systems subjected to organic fertilizations. Afr J Agr Res 10(2378-2388):8. https:// doi.org/10.5897/AJAR2016.11182

ANDA: Associação Nacional para difusão de Adubos (2016) Principais indicadores do setor de fertilizantes. http://anda.org.br/index .php?mpg=03.00.00. Accessed 21 Dec 2018

Azeez JOE, Averbeke W (2010) Nitrogen mineralization potential of three animal manures applied on a sandy clay loam soil. Bioresour Technol 101:5645-5651. https://doi.org/10.1016/j.biort ech.2010.01.119

Behera SK, Mathur RK, Shukla AK, Suresh K, Chandr P (2018) Spatial variability of soil properties and delineation of soil management zones of oil palm plantations grown in a hot and humid tropical region of southern India. CATENA 165:251-259. https://doi. org/10.1016/j.catena.2018.02.008

Boitt G (2014) Mineralogia e Distribuição das Formas de Fósforo em Latossolos com Diferentes Graus de Intemperismo. Dissertation, Universidade do Estado de Santa Catarina

Campos M, Antonangelo JA, Alleoni LRF (2016) Phosphorus sorption index in humid tropical soils. Soil Tillage Res 156:110-118. https ://doi.org/10.1016/j.still.2015.09.020

Carvajal-Muñoz JS, Carmona-Garcia CE (2012) Benefits and limitations of biofertilization in agricultural practices. Livestock Res Rural Develop 24:1-8 
Coletto AF, Almeida RF, Mikhael JER, Wendling B, Camargo R (2015) Chemical attributes of soil fertirrigated with biodigester effluent of swine origin. Aust J Crop Sci 9(5):431-437

Damatto Junior ER, Villas Boas RL, Leonel S, Fernandes DM (2006) Alterações em propriedades de solo adubado com doses de composto orgânico sob cultivo de bananeira. Rev Bras Frutic 28:546549. https://doi.org/10.1590/S0100-29452006000300048

Embrapa/Centro Nacional de Pesquisa de Solos (2013) Sistema brasileiro de classificação de solos, 3rd edn. Embrapa/CNPS, Rio de Janeiro

Embrapa-Empresa Brasileira de Pesquisa Agropecuária (2001) Compostagem. Comunicado técnico, Embrapa Agrobiologia, dez./2001, 11p

Embrapa-Empresa Brasileira de Pesquisa Agropecuária (2011) Manual de métodos de análise de solos/organizadores. https://www.infot eca.cnptia.embrapa.br/bitstream/doc/990374/1/ManualdeMtodosd eAnilisedeSolo.pdf. Accessed 2 July 2019

Faria IKP, Vieira JLV, Tenelli S, Almeida REM, Campos LJM, Costa RV, Zavaschi E, Almeida RF, Carneiro LMS, Otto R (2019) Optimal plant density and nitrogen rates for improving offseason corn yields in Brazil. Sci Agric 76:344-352. https://doi. org/10.1590/1678-992X-2017-0295

Fischer P, Pöthig R, Gücker B, Venohra V (2018) Phosphorus saturation and superficial fertilizer application as key parameters to assess the risk of diffuse phosphorus losses from agricultural soils in Brazil. Sci Total Environ 630:1515-1527. https://doi. org/10.1016/j.scitotenv.2018.02.070

Freitas MSC, Araújo CAS, Silva DJ (2012) Decomposição e liberação de nutrientes de estercos em função da profundidade e do tempo de incorporação. Rev Semiárido Visu 2:150-161

Hariadi YC, Nurhayati AY, Hariyani P (2016) Biophysical Monitoring on the Effect on Different Composition of Goat and Cow Manure on the Growth Response of Maize to Support Sustainability. Agric Ecosyst 9:118-127. https://doi.org/10.1016/j.aaspro.2016.02.135

Hoffmann I, Gerling D, Kyiogwom UB, Mané-Bielfeldt A (2001) Farmers management strategies to maintain soil fertility in a remote area in northwest Nigeria. Agric Ecosyst Environ 86:263275. https://doi.org/10.1016/S0167-8809(00)00288-7

Maciel TMS, Alves MC, Silva FC (2015) Atributos químicos da solução e do solo após aplicação de resíduo da extração de celulose. Rev Bras Eng Agríc Amb 19:84-90. https://doi. org/10.1590/1807-1929/agriambi.v19n1p84-90

Maggi CF, Freitas PSL, Sampaio SC, Dieter J (2011) Lixiviação de nutrientes em solo cultivado com aplicação de água residuária de suinocultura. Rev Bras Eng Agríc e Amb 15(2):170-177

Min J, Zhang H, Shi W (2012) Optimizing nitrogen input to reduce nitrate leaching loss in greenhouse vegetable production. Agric Water Manag 111:53-59. https://doi.org/10.1016/j.agwat .2012 .05 .003

Moreti D, Alves MC, Valério Filho WV, Carvalho MP (2007) Atributos químicos de um latossolo vermelho sob diferentes sistemas de preparo, adubações e plantas de cobertura. Rev Bras Cienc Solo 31:167-175. https://doi.org/10.1590/S0100-06832007000100017

Mota RP, Camargo R, Lemes EM, Lana RMQ, Almeida RF, Moraes ER (2019) Biosolid and sugarcane filter cake in the composition of organomineral fertilizer on soybean responses. Int J Recycl Org Waste Agric 8:131. https://doi.org/10.1007/s40093-018-0237-3

Moura JB, Ventura MVA, Cabral JSR, Azevedo WR (2015) Adsorção de Fósforo em Latossolo Vermelho Distrófico sob Vegetação de Cerrado em Rio Verde-GO. J Soc Technol Environ Sci 4:199-208. https://doi.org/10.21664/2238-8869.2015v4i3.p199-208

Muraishi CT, Alves MC, da Silva Júnior A, de Souza ZM (2011) Chemical attributes of a savannah Typic Hapludox soil under management systems. Acta Sci Agron 33:551-557. https://doi. org/10.4025/actasciagron.v33i3.6593

Nascimento CWA, Lima LHV, Silva FL, Biondi CM, Campos MCC (2018) Natural concentrations and reference values of heavy metals in sedimentary soils in the Brazilian Amazon. Environ Monit Assess 190:606. https://doi.org/10.1007/s10661-018-6989-4

Oliveira LB, Accioly AMA, Santos CLR, Flores RA, Barbosa FS (2014) Características químicas do solo e produção de biomassa de alface adubada com compostos orgânicos. Rev Bras Eng Agríc e Amb 18:157-164

Pinto FA, Santos FL, Terra FD, Ribeiro DO, Sousa RRJ, Souza ED, Carneiro MAC, Paulino HP (2012) Atributos de solo sob pastejo rotacionado em função da aplicação de cama de peru. Pesq Agropec Trop 42:254-262. https://doi.org/10.1590/S1983-4063201200 0300002

Ramos BZ, Toledo JPVF, Lima JM, Serafim ME, Bastos ARR, Guimarães PTG, Coscione AR (2013) Doses de gesso em cafeeiro: influência nos teores de cálcio, magnésio, potássio e pH na solução de um latossolo vermelho distrófico. Rev Bras Cienc Solo 37:1018-1026. https://doi.org/10.1590/S0100-0683201300 0400019

Sharma A, Ganguly R, Gupta AK (2019) Spectral characterization and quality assessment of organic compost for agricultural purposes. Int J Recycl Org Waste Agric 8:197. https://doi.org/10.1007/s4009 3-018-0233-7

Sikder S, Joardar JC (2019) Biochar production from poultry litter as management approach and effects on plant growth. Int J Recycl Org Waste Agric 8:47. https://doi.org/10.1007/s40093-018-0227-5

Silva DF, Matos AT, Pereira OG, Cecon PR, Moreira DA (2010) Disponibilidade de sódio em solo com capim tifton e aplicação de percolado de resíduo sólido. Rev Bras de Eng Agríc Amb 14:1094-1100. https://doi.org/10.1590/S1415-436620100010000 11

Silva VB, Silva AP, Dias BO, Araujo JP, Santos D, Franco RP (2014) Decomposição e liberação de N, P E K de esterco bovino e de cama de frango isolados ou misturados. Rev Bras Cienc Solo 38:1537-1546. https://doi.org/10.1590/S0100-068320140005000 19

Soil Survey Staff (2014) Keys to Soil Taxonomy, 12th edn. United States Department of Agriculture Natural Resources Conservation Service. https://www.nrcs.usda.gov/wps/portal/nrcs/detail/ soils/survey/class/taxonomy/?cid=nrcs142p2_053580. Accessed 2 Jan 2019

Sparovek G, Correche V, Alberto GO, Barretto P (2007) The risk of erosion in Brazilian cultivated pastures. Sci Agric 64:77-82. https ://doi.org/10.1590/S0103-90162007000100012

Trannin ICB, Siqueira JO, Moreira FMS (2005) Avaliação agronômica de um biossólido industrial para a cultura do milho. Pesq Agropec Bras 40:261-269. https://doi.org/10.1590/S0100-204X200500 0300010

Tripetchkul S, Pundee K, Koonsrisuk S, Akeprathumchai S (2012) Co-composting of coir pith and cow manure: initial $\mathrm{C} / \mathrm{N}$ ratio vs physico-chemical changes. Int J Recycl Org Waste Agric 1:15

Unuofin FO, Siswana M (2019) Enhancing organic waste decomposition with addition of phosphorus and calcium through different sources. Int J Recycl Org Waste Agric 8:139. https://doi. org/10.1007/s40093-018-0239-1

Publisher's Note Springer Nature remains neutral with regard to jurisdictional claims in published maps and institutional affiliations. 